\title{
EFFICIENCY ESTIMATION OF STRIPTILL SOIL PROCESSING TECNOLOGY
}

\author{
I.B. Borisenko ${ }^{1,3}$, O.G. Chamurliev ${ }^{1}$, \\ G.O. Chamurliev², M.V. Meznikova ${ }^{1}$ \\ ${ }^{1}$ Volgograd State Agricultural University \\ Universitetskiy pr., 26, Volgograd, 400002, Russian Federation \\ ${ }^{2}$ Scientific Research Institute of Design Vid Project \\ Olimpiyskay str., 1/2, Vidnoe, 142701, Russian Federation \\ ${ }^{3}$ Caspian Research Institute of Arid Agriculture \\ Severny district, $v$. Solenoe Zaimische, Chernoyarsky district, \\ Astrakhan region, 416251, Russian Federation
}

\begin{abstract}
This study explores the technology of chilling from the point of view of anthropogenic impact on soil. The influence of the arrangement of workers on technological rocessing is analyzed. The efficiency of resource-saving deep cultivation technology in production of row crops on example of sunflower growing in Volgograd region is estimated. We give technical and economic assessment of sunflower cultivation depending on the technological process of chilling. We defined a competitive technology of basic soil cultivation. Analysis of data obtained shows that the largest area of cross-section of the formation is produced when soil is treated with chisel tools as working organs are arranged such that they form a zone of continuous loosening, accordingly, it has the greatest anthropogenic impact. Field experiments also showed that deep loosening belts to a depth of $0.25 \ldots 0.35 \mathrm{~m}$, alternating with strips without treatment, are characterized by positive processes. Unprocessed areas become overcrowded (more than $1.3 \mathrm{~g} / \mathrm{cm}^{3}$ ), so they create less favorable, in comparison with processed, conditions for the development of some species of perennial weeds. Studies have shown that, with the main soil-free tillage of the soil to a depth of $0.3 \mathrm{~m}$, from the stubble of winter wheat, stubble conservation was consistent: $69.67 \%$ - over the treated band using striptill technology; $76.33 \%$ — on the processed strip by a chisel with a trail of $0.7 \mathrm{~m} ; 68.67 \%$ for a chisel with a trail of $0.35 \mathrm{~m}$. After the passage of the aggregates on the soil surface, all stubble remains within the requirements for SRT AIST 4.6-2010 (more than 60\%). The use of striptill technology reduces fuel costs by $35.5 \%$ relative to the classical chiesel, and by $27.3 \%$ relative to the minimum technology. Accordingly, the cost of wages is reduced by $37.5 \%$ compared to the classical chisel and by $24.8 \%$ compared to the minimum chisel technology.
\end{abstract}

Keywords: chiseling, band ripping, deep tillage, anthropogenic impact, striptill technology

\section{INTRODUCTION}

One of the most important ways of stabilizing and improving the economic efficiency of agricultural organizations is the further development of the intensification of production through the use of resource-saving technologies for the cultivation of agricultural crops. The right choice and rational use of soil-cultivating tools, as an executive tool of a sound manufacturing technology, is the main condition for ensuring the growth of productivity and profitability in agriculture. The greatest potential for cost reduction is in the area of basic deep tillage, while a stable reduction in costs is possible with a change in the tool setting that affects the process. 
The working organs of machines for processing soil of any type affect the natural environment. Such influence over time leads to a disturbance of the ecosystem. One of the main reasons for this phenomenon is the inconsistency of farming technology. For example, ploughing often leads to erosion of the fertile layer, salinization of soils may be an undesirable consequence of irrigation, and pasture of cattle is accompanied by degradation of grass cover with appearance of conditions for erosion. Anthropogenic impact on soil can be characterized, in particular, by the mechanical destruction of natural environment, determined not only by depth, but also by cross-sectional area. The result of such undesirable effects is described by anthropogenic factor [1]. To study degree of influence of strip farming on environment, we have chosen anthropogenic impact. This made it possible to compare the various technological processes of soil cultivation, on the basis of an implement with chisel working tools, arranged with various interinheritance, providing outcropping to surface [2] and additional device [3] limiting zone of deformation (Strip-till) with a classic chisel, providing a zone of continuous loosening.

\section{MATERIALS AND METHODS}

To minimize anthropogenic impact on the soil, it is recommended to reduce energy costs, in particular, depth of processing. That is, change in anthropogenic impact can be characterized by the cross-sectional area of the treated formation. This fact is actual in the production of row crops, the cultivation of which provides a strip mechanical effect on the medium to be treated, as a promising environmental and economical technology. Indicators of rational use and economical use of material and energy resources, expressed in quantitative form, are the requirements of resource use and resource saving [4]. The established indicators of resource use should provide an opportunity to effective assess of resource-saving requirements. The indicator, determined by the ratio of a particular parameter to another, is the specific indicator of resource use.

Considering the fact that for different technologies ratio of treated part of soil to untreated part differs significantly, it can be assumed that the smaller the given dependence in terms of the perimeter of tool capture width, the more effective the technology of soil cultivation from the resource saving point of view. Given that the same chisel tool, working at the same depth, but tuned to a different technological process, it is logical to compare their anthropogenic impact on the meter. In this regard, we introduce the concept of anthropogenic impact coefficient of soil-cultivating tools.

Anthropogenic impact on soil can be characterized by coefficient $K_{a i}$ determined by ratio of loosening area $S_{l}$ in the transverse plane to working width $B_{w}$ of the tool gripping, taking into account the depth $h_{c h}$ of its processing:

$$
K_{a i}=\frac{F}{B_{w} h_{c h}},
$$

where $F$ - area of loosening of the formation in the transverse plane, $\mathrm{m}^{2} ; B_{w}$ - working width of the tool, $\mathrm{m} ; h_{c h}$ - depth of processing (chiseling), $\mathrm{m}$.

Figures $1-3$ show transverse profile diagrams of formation when chisel tool is operated using solid, strip and striptill technologies, respectively. 


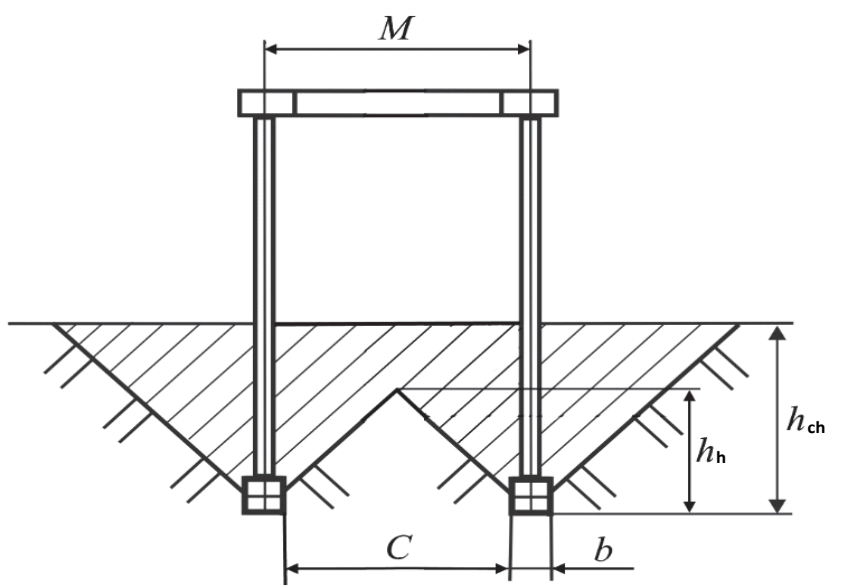

Fig. 1. Scheme of transverse profile of formation during operation of chisel tool

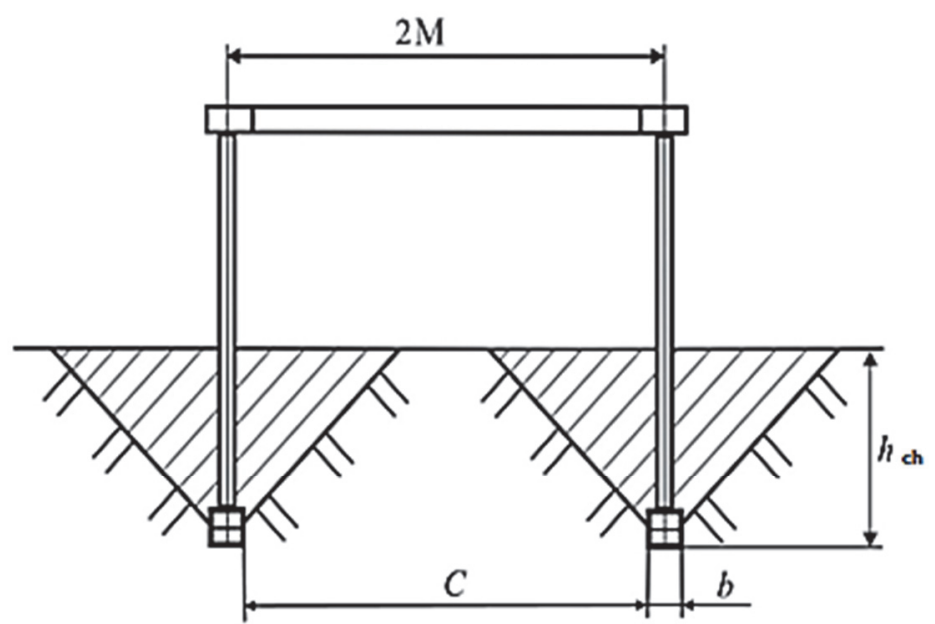

Fig. 2. Scheme of transverse profile of formation during operation of chisel tool using technology of strip processing of soil

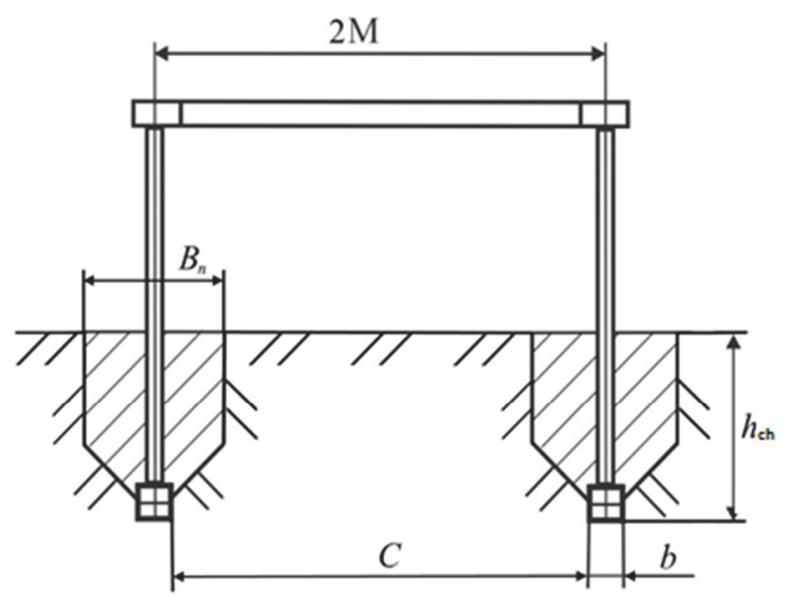

Fig. 3. Scheme of transverse profile of formation during operation cultivation tools for striptill technology 
Taking into account the scheme of transverse profile of formation during the operation of chisel tool using continuous loosening technology (Figure 1) and assuming value of soil deformation angle $90^{\circ}$, the loosening area $F_{k \pi}$ transverse plane within working (technological) width of the $B_{w}$, tool is determined by depth product difference processing $h_{c h}$ on the interfluve $M$ and area of intrasoil comb multiplied by the number of working bodies $n$. After the transformation, the relationship takes the form:

$$
F_{k}=n\left(h_{\mathrm{q}} M-\frac{(M-b)^{2}}{4}\right),
$$

Taking into account the above, cross-sectional area of loosened part of formation, when processed using strip-chisel technology, the form is:

$$
F_{k \Pi}=n_{\Pi} h_{\mathrm{q}}\left(h_{\mathrm{u}}+b\right) \text {. }
$$

Accordingly, cross-sectional area of loosened part of formation when processing the soil using stripteel technology,

$$
F_{k \mathrm{c}}=n\left[h_{\mathrm{ч}} B_{\Pi}-\left(\frac{B_{\Pi}-b}{2}\right)^{2}\right] .
$$

Figure 4 shows the dependence of cross-sectional area of loosened part of formation from depth, taking into account technology of soil cultivation. As can be seen from the graph, the largest cross-sectional area of loosened part of formation is formed with continuous chiseling. This is explained by the increment of the zone of continuous loosening with increasing depth of processing. The least intensity is the strip technology as a result of cutting zone of deformation of soil with disc knives.

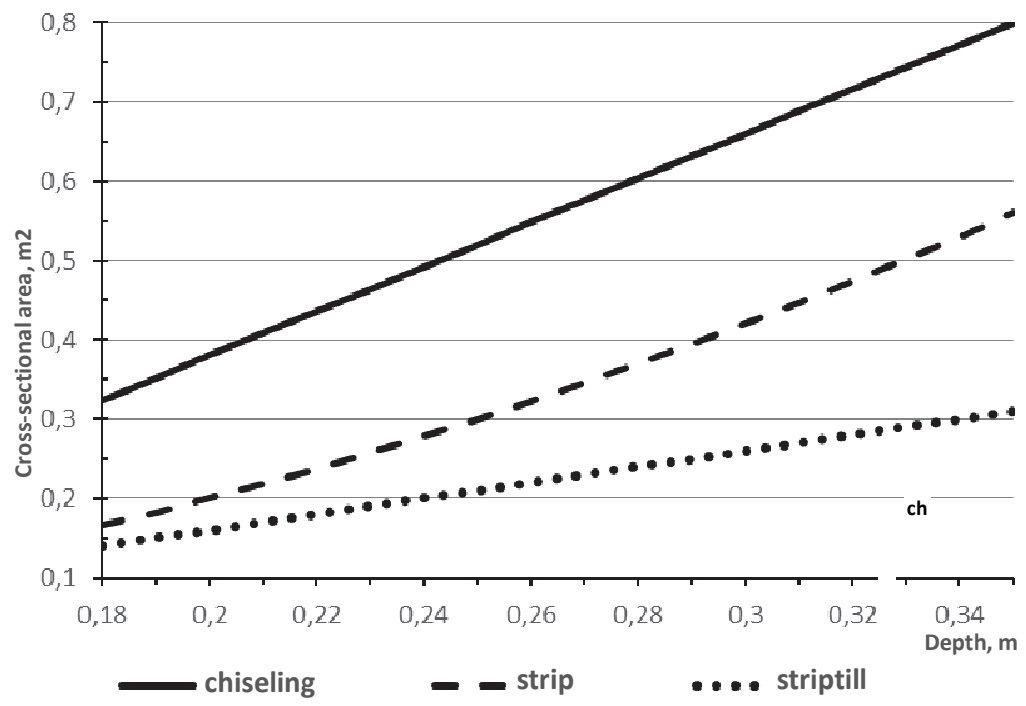

Fig. 4. Dependence of cross-sectional area of loosened part of formation from depth, taking into account processing technology 
The product of the working width $B_{w}$ of tool gripping to depth $h_{c h}$ is equal to the area of loosening with chiseling, without taking into account intrusive grooves, which determines cross-sectional area when flat-cutting tool is operating.

The theoretical working width of the tool is determined by product of number of working tools on inter-stage of their arrangement in transverse plane. Taking into account the above, expressions for determining the coefficient of anthropogenic impact on soil in case of chilling depending on the technological process of processing are:

for continuous chilling

$$
K_{\text {aich }}=\left(h_{c h} M-\frac{(M-b)^{2}}{4}\right) / M h_{c h},
$$

for strip chiseling

$$
K_{\text {авп }}=\left(h_{\mathrm{q}}+b\right) / M_{\Pi},
$$

for striptill technology

$$
K_{\text {авс }}=\left(h_{\mathrm{q}} B_{\Pi}-\left(\frac{B_{\Pi}-b}{2}\right)^{2}\right) / M_{\mathrm{c}} h_{\mathrm{q}} .
$$

According to the given expressions (5,6 and 7), taking into account the adopted values of width of inter-trace (for chiseling - $0.35 \mathrm{~m}$, strip and striptill treatments $0.7 \mathrm{~m}$ ), bit $0.05 \mathrm{~m}$, strip $0.25 \mathrm{~m}$. Calculated dependences are obtained and graphs are plotted (Fig. 5) for the effect of chilling depth on change in the coefficient of anthropogenic treatment effect for various technological processes of chilling.

According to the graph, the coefficient of anthropogenic impact on the soil with technology of strip chiseling with respect to classical chiseling decreases with increasing depth of processing from 2 to 1.43 times. With striptill it increases from 2.18 to 2.58 times.

Intensity of increase in coefficient of anthropogenic impact on soil with striptill technology relative to band-wise chiseling also increases with increasing depth of processing, but with greater intensity, from 1.09 to 1.81 times. This situation is explained by different intensity of increment in the area of soil cultivation for selected technological processes.

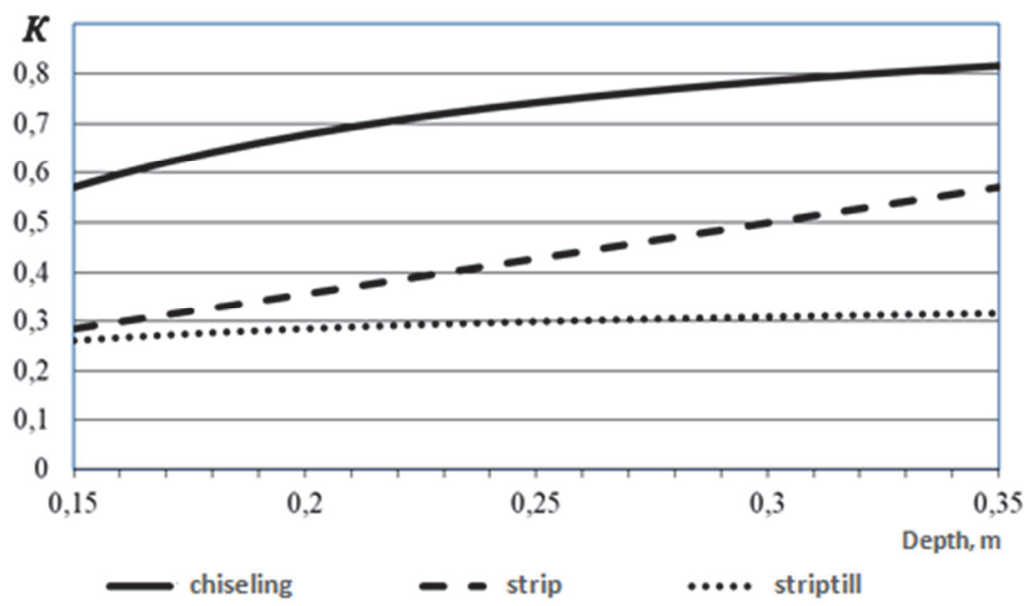

Fig. 5. Dependence of change in coefficient of anthropogenic impact on depth, for various technologies of soil cultivation 
Thus, when comparing the studied soil treatment technologies by the factor of anthropogenic impact, it was found that the least coefficient of anthropogenic impact in striptill technology is due to the fact that only a part of the strip is processed. And taking into account running meter, this technology favorably differs from classical and strip chisel processing concerning anthropogenic factor.

\section{RESULTS AND DISCUSSION}

During the field experiments, we obtained results of measuring loosening area of cross section of running meter of cultivated crop for various soil cultivation technologies. The studies were carried out for a chisel tool with a trace of working tools of $0.35 \mathrm{~m}$; chisel tool for strip processing of soil with a trace of working bodies $0.70 \mathrm{~m}$; tools for strip processing by striptill technology (with working tools on the frame of the tool with a trail $0.7 \mathrm{~m}$ ). The data obtained were analyzed for determination of technological unloading coefficient $K_{p}$. This coefficient represents the share of the processing area of the applied technology relative to the area under continuous processing at the same depth and is determined by the ratio of processing areas of technology under consideration with respect to continuous loosening, per running meter of the cultivated crop:

$$
K_{p}=\frac{h^{*} B_{\text {пм }}}{S_{\text {пм }}},
$$

where $B_{\mathrm{rm}}$ - the width of the running meter of the cultivated crop, equal to the width of the aisle or between strip distance with the cultivated crop; $h$ - depth of processing; $S_{\mathrm{rm}}$ - the processing area of technology under investigation per meter of cultivated crop.

The results of measurements and calculations are presented in Table 1.

Table 1

Area of loosening by types of basic processing

\begin{tabular}{|c|c|c|c|}
\hline \multirow{2}{*}{$\begin{array}{c}\text { Depth } \\
h_{c h}, \mathrm{~m}\end{array}$} & \multicolumn{2}{|c|}{ Loosening area, $\mathrm{m}^{2} /$ Coefficient of technological unloading } \\
\cline { 2 - 4 } & Chisel & Strip processing & Striptill \\
\hline 0.2 & $0.097 / 1.45$ & $0.049 / 2.85$ & $0.041 / 3.43$ \\
\hline 0.25 & $0.146 / 1.20$ & $0.083 / 2.10$ & $0.055 / 3.18$ \\
\hline 0.3 & $0.157 / 1.34$ & $0.110 / 1.91$ & $0.064 / 3.27$ \\
\hline 0.35 & $0.190 / 1.29$ & $0.133 / 1.84$ & $0.076 / 3.23$ \\
\hline 0.4 & $0.204 / 1.37$ & $0.163 / 1.72$ & $0.093 / 3.00$ \\
\hline
\end{tabular}

According to the results of the study of loosening area, depending on the depth for different processing technologies, a graph was made (Figure 6).

Change in the coefficients of technological unloading for chilling, strip processing and striptill technology depending on the depth of treatments is shown in Figure 7.

Analysis of the data shows that the largest cross-sectional area of formation is formed when soil is treated with a chisel tool with working organs arranged so that they form a zone of continuous ripping, and accordingly it has the greatest anthropogenic impact. 


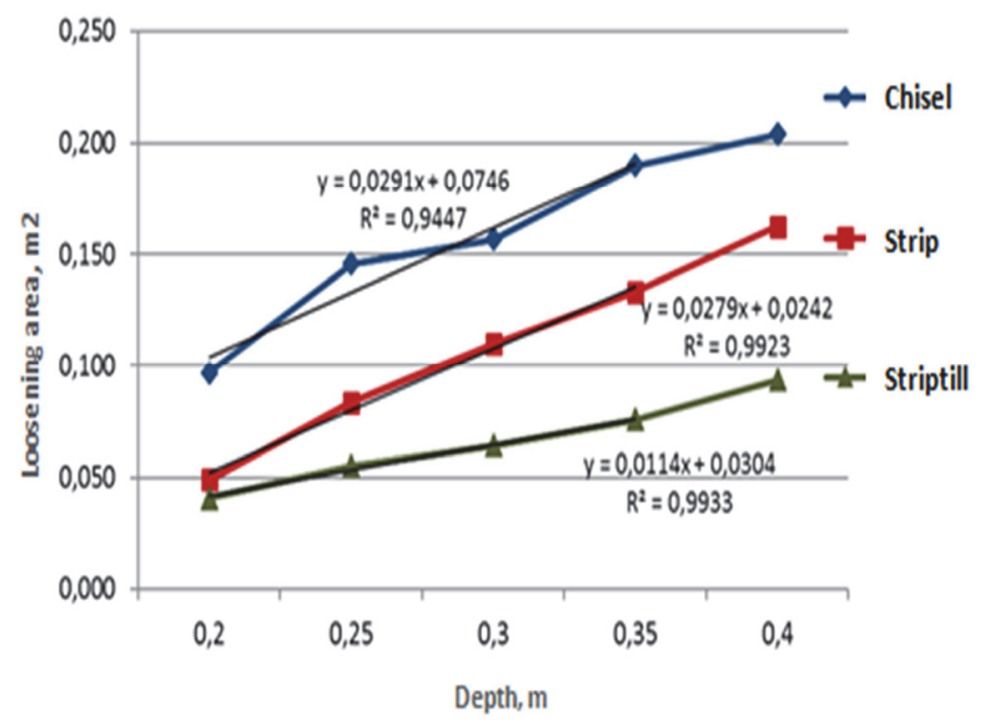

Fig. 6. Dependence of loosening area of running meter of cultivated crop from depth of processing for various technologies

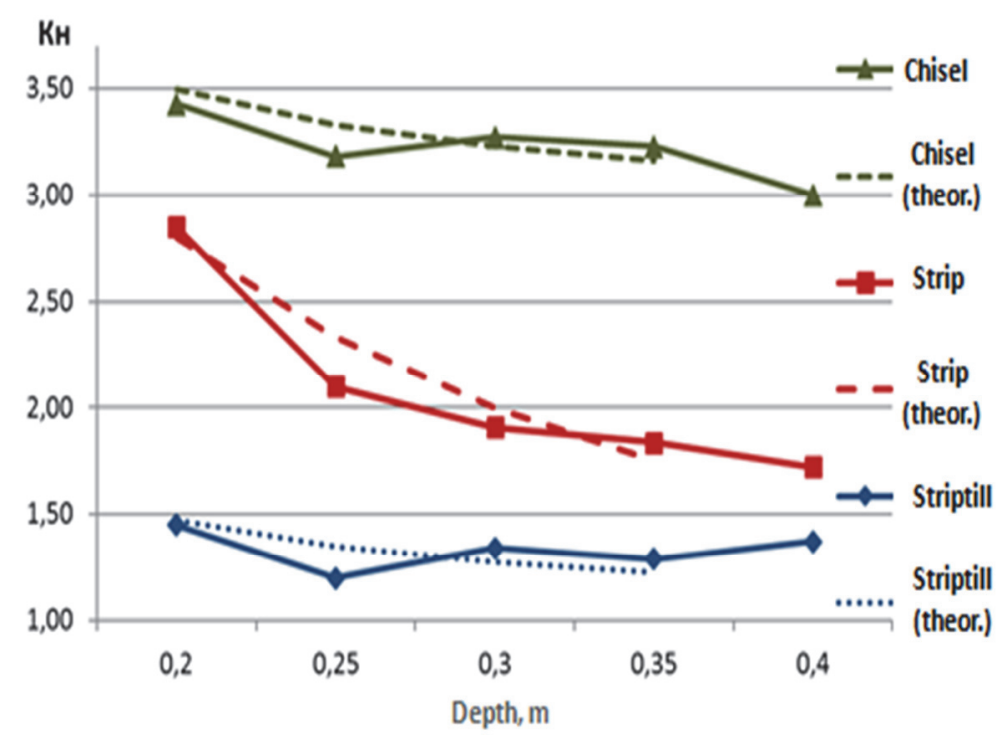

Fig. 7. Dependence of coefficient of technological unloading on depth of processing depending on technology

When chiseling in technology of strip processing, the area of loosening is much lower. This is explained by arrangement of chisel working tools on tool frame without formation of continuous loosening zone. With striptill technology (with disc knives), loosening area is the smallest with the same depth of processing. This is due to cutoff of deformation zone from chisel bit by means of disc knives.

Field experiments also showed that deep loosening belts to a depth of $0.25 \ldots 0.35 \mathrm{~m}$, alternating with strips without treatment, are characterized by positive processes. Unprocessed areas become overcrowded (more than $1.3 \mathrm{~g} / \mathrm{cm}^{3}$ ), so they create less favorable 
conditions for development of some species of perennial weeds in comparison with processed areas. Studies [5] indicate presence of cyst-forming nematodes in dense soil $\left(9\right.$ cysts per $\left.100 \mathrm{~cm}^{3}\right)$. There is an increase in nematode number in loose soil. In untreated areas, a sharp decrease in density of pathogen population (F. graminearum and $R$. solani) was found, and disease developed less frequently. Remaining stubble on untreated soil surface delayed this process by approximately 50\% (104 weeks) compared to treated soil. Studies have shown that with the basic soil-free tillage of the soil to a depth of $0.3 \mathrm{~m}$, along the stubble of winter wheat, the stubble conservation corresponded to: $69.67 \%$ - over the treated band using striptill technology; $76.33 \%$ — on processed strip by a chisel with a trail of $0.7 \mathrm{~m} ; 68.67 \%$ - for a chisel with a trail of $0.35 \mathrm{~m}$. After passage of aggregates on soil surface, all stubble remains within the requirements for STO AIST 4.6-2010 (more than 60\%).

Figure 8 shows the results of influence of soil tillage technology on stubble conservation, as well as the conservation of stubble, taking into account the conversion to a linear meter in the production of row crops with row spacing of $0.7 \mathrm{~m}$.

The production check of effectiveness of strip-technology was carried out on the basis of data obtained at the Elansk branch of Volgograd Agro-Industrial Company at the price level for 2017. Calculation of technical and economic efficiency of the technology of soil strip processing was carried out on the basis of the technique [6]. For execution of settlement operations the software product Microsoft Excel was used.

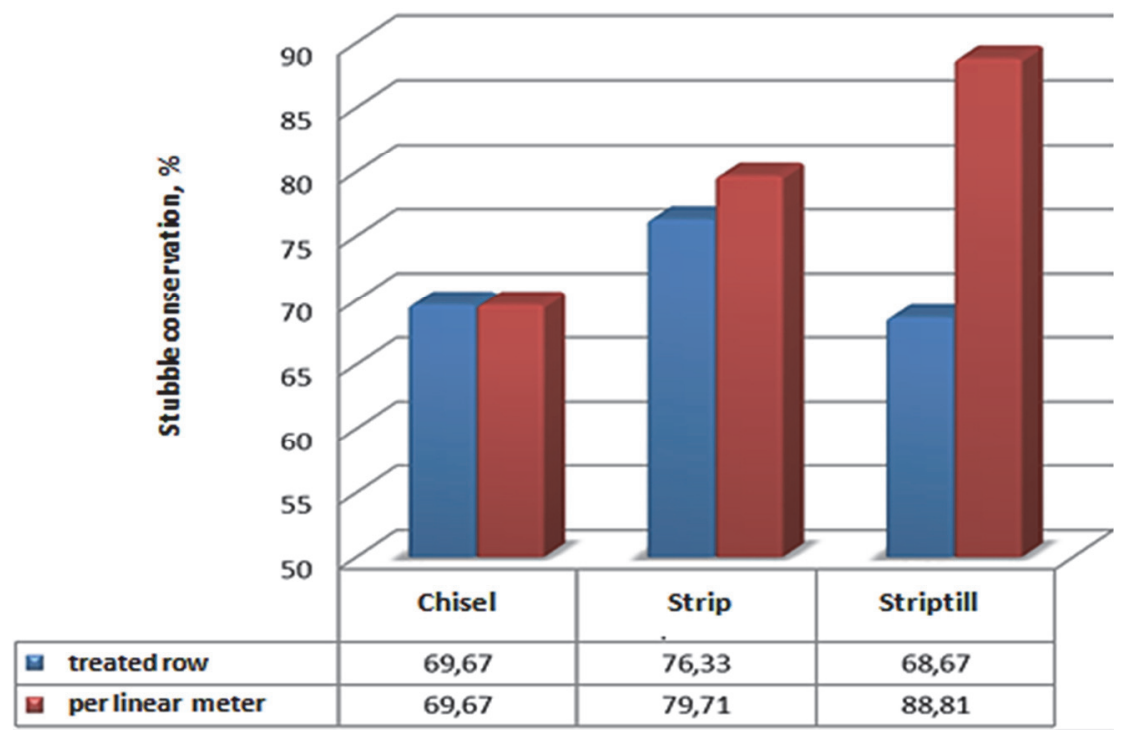

Fig. 8. Effect of soil tillage technology on stubble conservation

Currently, several basic tillage types are used in sunflower cultivation in Yelansk branch of Volgograd Agro-Industrial Company. In one part of the area two-phase processing using strip-till technology is used. According to the technology, in autumn soil is treated with strips to a depth of $0.23 \ldots 0.25 \mathrm{~m}$, and in spring it is produced by sowing agricultural crops. The other part of the area is treated according to minimal technology based on chisel processing, and weed control is carried out both mechanically 
(intercultural cultivation) and chemical (application of pesticides). In the first and third cases, processing with a rate of application of $11 /$ ha is used for this purpose. In addition, in strip technology for preventive purposes during the autumn processing of strips, glyphosate was used to control weeds in the fields during the spring period.

According to the program on the basis of the MicrosoftExcel we developed product, composition and need for number and employment of units, taking into account area of production of agricultural products. Table 2 summarizes use of machines and aggregates in sunflower production for various technologies used in the farm.

Table 2

Use of machines and aggregates in sunflower production depending on various cultivation technologies

\begin{tabular}{|c|c|c|c|c|c|c|}
\hline № & Model & Number & Price, rub. & $\begin{array}{c}\text { Earning } \\
\text { rub/h }\end{array}$ & $\begin{array}{c}\text { Costs per } \\
\text { hectare } \\
\text { rub/ha }\end{array}$ & Total \\
\hline 1. & JohnDeere 9430 & 1 & $9,745,763$ & 1804.77 & & $9,745,763$ \\
\hline 2. & MT3-1221 & 1 & $2,240,000$ & 553.09 & & $2,240,000$ \\
\hline 3. & ClaasTucano 450 & 2 & $8,474,576$ & 6277.46 & 1393.44 & $16,949,152$ \\
\hline 4. & Amazone ZAM-900 & 1 & 169,492 & 125.55 & 6.15 & 169,492 \\
\hline 5. & Orthman 1 tRIPr & 1 & $1,881,356$ & 1393.60 & 215.73 & $1,881,356$ \\
\hline 6. & Bourgault 8910 & 1 & $5,254,237$ & 3892.03 & 572.36 & $5,254,237$ \\
\hline 7. & Hardi-Commandor 3200 & 1 & $1,694,915$ & 1255.49 & 61.54 & $1,694,915$ \\
\hline 8. & Zhatka & 2 & 1 & 0.00 & 0.00 & 0 \\
\hline 9. & Striegel & 1 & 336,441 & 249.22 & 16.29 & 336,441 \\
\hline 10. & John Deere-512 & 1 & 750,000 & 555.56 & 134.21 & 750,000 \\
\hline 11. & KKZ-10 & 1 & 452,210 & 334.97 & 34.27 & 452,210 \\
\hline 12. & $\mathrm{KRN}-5,6$ & 2 & 195,510 & 144.82 & 30.42 & 391,020 \\
\hline \multicolumn{5}{|c|}{ Total for striptill technology } & & $37,934,915$ \\
\hline \multicolumn{5}{|c|}{ Total for classical chisel technology } & & $36,288,315$ \\
\hline \multicolumn{5}{|c|}{ Total for minimal chisel technology } & & $37,140,000$ \\
\hline
\end{tabular}

Cost of machines for classical chisel processing requires an investment of 851,685 rubles which is less than for minimal chisel technology. This is due to the need to purchase machines for combating weeds. In one case, the machines are used for mechanical control of weeds, in another case - for chemical control. Cost of machines for strip technology from the presented technologies is the highest (in comparison with classical chisel which is $1,646,600$ rubles more, compared to the minimum chisel which is 794,915 rubles more). This is due to the high cost of machines for strip cultivation. Virtually all of the tools for strip production are imported, and in the face of ambiguous conditions in the economic arena, their prices are continuously rising. In this regard, we would like to focus our current work on development and introduction of domestic production machines for strip processing. This will reduce the cost of such machines significantly and consequently make strip technology the most attractive for farmers.

Figure 9 shows histogram of influence of sunflower cultivation technology on amount of direct technical costs.

Based on calculation, histograms of influence of sunflower cultivation technology on value of direct production costs have been constructed (Figure 10). 
Cost, rub.

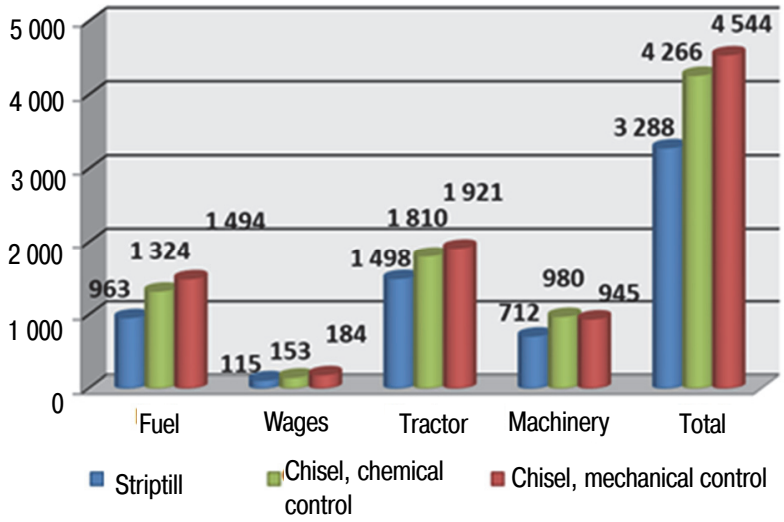

Fig. 9. Influence of sunflower cultivation technology on direct technical cost
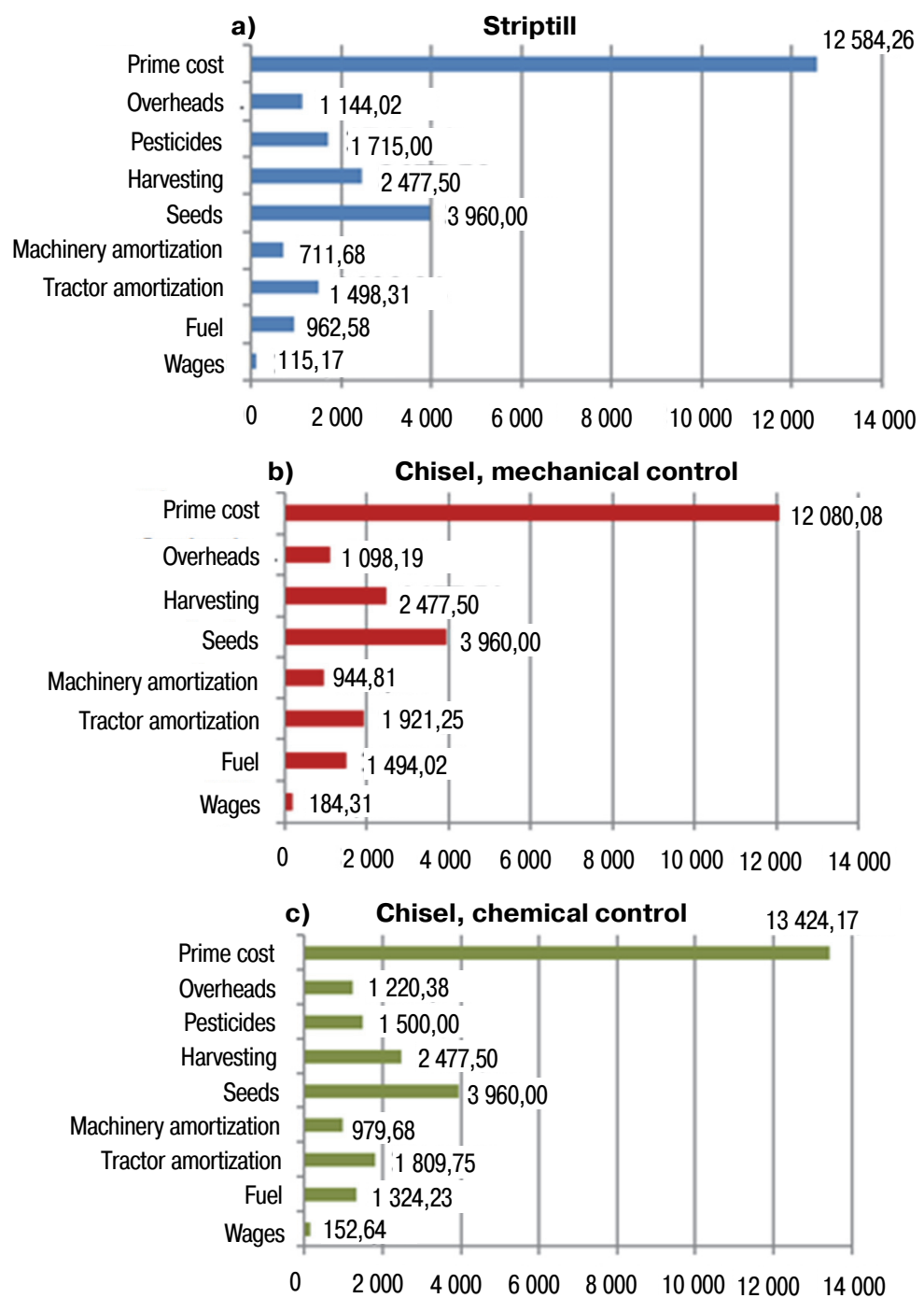

Fig. 10. Structure of direct production costs in sunflower cultivation depending on technology of basic processing:

a) striptill technology; b) chiseling with inter-row machining;

c) chiseling with application of chemical pesticides 


\section{CONCLUSIONS}

Analysis of the data obtained shows that degree of anthropogenic impact depends on arrangement of working organs on tool frame. The lowest coefficient is in strip processing technology.

Striptill technology has the lowest costs $(3,288$ rubles per hectare). This is due to both a reduction in operations and a smaller number of units in the ICC. In terms of direct costs the most expensive is classical chisel technology (4,544 rubles per hectare). Minimal chisel technology takes middle position (4,266 rubles per hectare). Striptill technology reduces fuel costs by $35.5 \%$ compared to classical chisel, and by $27.3 \%$ compared to minimum technology. Wages is reduced by $37.5 \%$ and $24.8 \%$ compared to classical chisel and minimum chisel technology, respectively. The magnitude of these changes is explained by decrease in number of technological operations of mechanical tillage, which reduces range of agricultural machines at the same time as costs of their purchase and depreciation charges, as well as required amount of fuel. Accordingly, the total direct technical costs for the classical chisel are lowered by $22.9 \%$ and for the minimal chisel technology are reduced by $27.6 \%$.

(C) I.B. Borisenko, O.G. Chamurliev,

G.O. Chamurliev, M.V. Meznikova, 2018.

\section{REFERENCES}

[1] Shabaev AI. Adaptivno-ekologicheskie sel'skokhozyaistvennye sistemy v agrolandshaftakh Povolzh'ya [Adaptive-ecological farming systems in agrolandscapes of Volga Region]. Saratov; 2003. 344 p. (In Russ).

[2] Patent RUS № 1544634/27.08.15. Byul. № 24. Borisenko IB, Borisenko PI, Pleskachev YN, et al. Plug-rykhlitel' [Ripper plow]. (In Russ).

[3] Patent RUS № 2544950/20.03.15. Byul. № 8. Borisenko IB, Pleskachev YN, Sokolova MV. Orudie dlya reguliruemoi polosnoi glubokoi obrabotki pochvy [Instrument for controlled strip deep cultivation]. (In Russ).

[4] GOST (Russian State Standard) R 52778 - 2007 Testirovanie sel'skokho-zyaistvennoi tekhniki. Metody operativnoi i tekhnologicheskoi otsenki [Testing of agricultural machinery. Methods of operational and technological evaluation]. Moscow: Standartinform Publ.; 2008. (In Russ).

[5] Kurmanbaev SK, Dzhamanova GI. Ekologicheskie osnovy organizatsii zashchity rastenii: uchebnik dlya magistrov sel'skokhozyaistvennykh vuzov [Ecological foundations of plant protection: a textbook for undergraduates of agricultural universities]. Semei Publ.; 2016. 205 p. (In Russ).

[6] Ovchinnikov AS, Pleskachev YN., Borisenko IB, Tseplyaev AN. Registr tekhnologii proizvodstva zernovykh, zernobobovykh, krupyanykh i maslichnykh kul'tur v Volgogradskoi oblasti [Register of technologies for production of ce-reals, legumes and oilseeds in Volgograd region]. Volgograd: Volgogradskii GAU Publ.; 2012. 148 p. (In Russ).

\section{Author's personal data:}

Ivan Borisovich Borisenko - Doctor of Engineering Science, senior researcher, professor of Volgograd State Agricultural University; e-mail: borisenivan@yandex.ru

Omariy Georgievich Chamurliev - Doctor of Agricultural Science, Volgograd State Agricultural University, e-mail: attika.ge@yandex.ru

Georgiy Omarievich Chamurliev - Candidate of Agricultural Science, Scientific Research Institute of Design «Vid Project», e-mail: giorgostsamourlidis@mail.ru

Maria Viktorovna Meznikova - Senior Lecturer of Volgograd State Agricultural University; e-mail: marina_roxette@mail.ru 


\title{
For citation:
}

Borisenko I.B., Chamurliev O.G., Chamurliev G.O., Meznikova M.V. Efficiency estimation of strip soil processing tecnology. RUDN Journal of Agronomy and Animal Industries, 2018, 13 (3), 194 206. doi: 10.22363/2312-797X-2018-13-3-194-206.

\section{ОЦЕНКА ЭФФЕКТИВНОСТИ ТЕХНОЛОГИИ ПОЛОСНОЙ ОБРАБОТКИ ПОЧВЫ}

\author{
И.Б. Борисенко ${ }^{1,3}$, О.Г. Чамурлиев ${ }^{1}$, \\ Г.О. Чамурлиев ${ }^{2}$, М.В. Мезникова ${ }^{1}$ \\ ${ }^{1}$ Волгоградский государственный аграрный университет \\ Университетский пр., 26, Волгоград, 400002, Российская Федераџия \\ ${ }^{2}$ Научно-исследовательский и проектный институт «Вид Проект» \\ Олимпийская ул., 1 корп. 2, Видное, Московская обл., 142703, Российская Федераџия \\ ${ }^{3}$ Прикаспийский научно-исследовательский институт аридного земледелия \\ Северный квартал, с. Соленое Займище, Черноярский район, \\ Астраханская область, 416251, Российская Федерачия
}

В статье рассмотрена технология чизелевания с позиции антропогенного воздействия на почву. Проанализировано влияние расстановки рабочих на технологический процесс обработки. Дана оценка эффективности ресурсосберегающей технологии глубокой обработки почвы при производстве пропашных культур на примере выращивания подсолнечника на территории Волгоградской области. Дана технико-экономическая оценка возделывания подсолнечника в зависимости от технологического процесса чизелевания. Определена конкурентоспособная технология основной обработки почвы. Анализ полученных данных показывает, что наибольшая площадь поперечного сечения пласта образуется при обработке почвы буровыми инструментами, поскольку рабочие органы расположены так, что они образуют зону непрерывного рыхления, соответственно, она оказывает наибольшее антропогенное воздействие. Полевые эксперименты также показали, что глубокие рыхлые ленты на глубину $0,25 \ldots 0,35$ м, чередующиеся с полосками без обработки, характеризуются положительными процессами. Необработанные площади становятся загущенными (более $1,3 \mathrm{r} / \mathrm{cm}^{3}$ ), поэтому они создают менее благоприятные по сравнению с обработанными условия для развития некоторых видов многолетних сорняков. Исследования показали, что после основной обработки почвы на глубину 0,3 м с использованием технологии полосной обработки почвы сохранялось $69,67 \%$ стерни озимой пшеницы. Использование технологии полосной обработки почвы снижает затраты на топливо на $35,5 \%$ по сравнению с классическим обработкой и на $27,3 \%$ относительно минимальной технологии. Соответственно, стоимость заработной платы снижается на $37,5 \%$ по сравнению с классической схемой и на $24,8 \%$ по сравнению с минимальной технологией.

Ключевые слова: глубокая обработка почвы, антропогенное воздействие, технология стриптил, полосная обработка почвы

\section{БИБЛИОГРАФИЧЕСКИЙ СПИСОК}

[1] Шабаев А.И. Адаптивно-экологичские системы земледелия в агроландшафтах Поволжья / А.И. Шабаев. Саратов, 2003.

[2] Патент РФ № 1544634/27.08.15. Бюл. № 24. Борисенко И.Б., Борисенко П.И., Плескачев Ю.Н. [и др.]. Плуг-рыхлитель. 
[3] Патент РФ № 2544950/20.03.15. Бюл. № 8. Борисенко И.Б., Плескачев Ю.Н., Соколова М.Н. / Орудие для регулируемой полосной глубокой обработки почвы.

[4] ГОСТ Р 52778-2007 Испытания сельскохозяйственной техники. Методы эксплуатационнотехнологической оценки. Москва: Стандартинформ, 2008.

[5] Курманбаев С.К., Джаманова Г.И. Экологические основы организации защиты растений. Учебное пособие. Семей, 2016.

[6] Овчинников А.С. Регистр технологий производства зерновых, зернобобовых, крупяных и масличных культур в Волгоградской области / Сост. А.С. Овчинников, Ю.Н. Плескачев, И.Б. Борисенко, А.Н. Цепляев. Волгоград: ФГОУ ВПО «Волгоградский ГАУ», 2012.

\section{Для цитирования:}

Борисенко И.Б., Чамурлиев О.Г., Чамурлиев Г.О., Мезникова М.В. Оценка эффективности технологии полосной обработки почвы // Вестник Российского университета дружбы народов. Серия: Агрономия и животноводство. 2018. Т. 13. № 3. С. 194-206. doi: 10.22363/2312-797Х2018-13-3-194-206. 